\title{
THE FACTORS INFLUENCING EXTERNAL AUDIT AND THE EFFECT OF EXTERNAL AUDIT ON FISCAL TRANSPARENCY
}

\author{
Hüseyin Güçlü ÇiçEK ${ }^{1}$
}

\author{
Süleyman DiKMEN²
}

\begin{abstract}
The study aims to analyze the factors that affect the external audit of the Supreme Audit Institution (SAI) and the effects of external audit on fiscal transparency. The effect of external audit on fiscal transparency is tested for 115 countries with Two-Stage Least Squares Method (2SLS). According to the analysis, it is determined that the level of democratization, gross domestic product (GDP) per capita, budget oversight of the legislature, audit diversity of Supreme Audit Institution and judicial model of Supreme Audit Institution have significant and positive effects on external audit. It is also determined that external audit has significant and positive effects on fiscal transparency.
\end{abstract}

Keywords: External Audit, Fiscal Transparency, Supreme Audit Institution, Two-Stage Least Squares Method (2SLS).

JEL Code: H60, H83.

\section{Introduction}

Fiscal transparency and accountability are the main components of democratic societies in terms of collection and expenditure of public revenues. Citizens have the power to decide on the collection of public revenues and the realization of public expenditures. Citizens now use these powers through legislatures in representative democracies(Yılmaz \& Biçer, 2010: 206). As a requirement of the transfer of authority, the government is supposed to be open to the citizens, share information and account for the use and management of public resources. Today, governments set up effective control mechanisms to perform these functions, and in every democratic country there is a Supreme Audit Institution (SAI). The Supreme Audit Institution ensures independent audit of public accounts, as well as plans, programs, projects and other activities carried out by the government.In this study, the factors affecting the external audit performed by the Supreme Audit Institution and the effects of external audit on fiscal transparency have been analyzed.

\section{Literature Review}

The Supreme Audit Institution is the national body responsible for auditing the government's income and expenses. Governments have many duties regulated in their legislation, but their main task is to audit the management of public resources and the quality and reliability of government fiscal data(Stapenhurst \& Titsworth, 2001: 1). The audit carried out by the Supreme

\footnotetext{
1 Assoc. Prof., Süleyman Demirel University, Faculty of Economics and Administrative Sciences, Public Finance Department, huseyincicek@sdu.edu.tr

2 Dr., Süleyman Demirel University, Faculty of Economics and Administrative Sciences, Public Finance Department, suleymandikmen@sdu.edu.tr
} 
Audit Institutions is considered as external audit or supreme audit in the literature (Köse, 2007: 17). External audit is an external assessment conducted by an independent body outside the assessed institution (Posner \& Shahan, 2014: 489). By taking the evaluations made into consideration, deputies and citizens keep the members of the government responsible in the fields of political elections, parliament negotiations and public debates and hold them liable for it(Bringselius, 2015: 150). In a country, the main element that ensures a transparent state administration is a reliable audit (Feyzioğlu, 1997: 7). In other words, fiscal transparency is the prerequisite for actualization of external audit (Morgner \& Chêne, 2014: 3). It is of crucial importance for the government to be transparent for an effective external audit. Fiscal transparency increases as the Supreme Audit Institution implements an effective external audit. Thus, a bilateral relation exits between fiscal transparency and external audit and this situation has been defined as reverse causality in literature (Santiso, 2006, 2007a, 2007b).

\section{Data and Variables}

The main purpose of this study is to determine the socio-economic, institutional and political factors that affect the external audit conducted by the Supreme Audit Institution within the framework of an international comparison. Open Budget Survey of International Budget Partnership dated 2017 has been used in order to measure external audit and fiscal transparency. The survey covering 115 countries is the world's unique independent and comparative fiscal transparency measurement. As the survey data belonging 2017 were gathered in the year 2016, the data related to other variables belong to year 2016.

In the study, the factors affecting external audit have been grouped in two categories and independent variables have been classified in the scope of this grouping as well. According to this grouping, the elements affecting external audit are; (i) socio-economic factors and (ii) political and institutional factors. The socio-economic factors affecting external audit are; economic development level ( $g d p p c)$, government debt (debt), government balance (government.balance), democratization level (democracy). The political and institutional factors include the variables such as legislative budget oversight (leg.oversight), judicial model of Supreme Audit Institution (judicial.SAl) and audit diversity (audit.diversity).

On Table 1, calculation methods of dependent and independent variables and explanations related to the data sources take place. 
Table 1. Explanatory Information Regarding Variables

\begin{tabular}{|c|c|c|c|}
\hline Variable & Explanation & Calculation Method & Source \\
\hline \multicolumn{4}{|c|}{ Dependent Variables } \\
\hline external.audit & External Audit & external.audit $=\sum_{i=1}^{6}\left(\right.$ external.audit $\left.{ }_{i}\right) / 6$ & $\begin{array}{l}\text { It was compiled by us } \\
\text { using the } 2017 \text { Open } \\
\text { Budget Survey Data. }\end{array}$ \\
\hline fiscal.transparency & $\begin{array}{l}\text { Fiscal } \\
\text { Transparency }\end{array}$ & $\begin{array}{l}\text { OBI: 0: less or zero information; 100: detailed } \\
\text { information }\end{array}$ & $\begin{array}{l}\text { International Budget } \\
\text { Partnership (IBP) }\end{array}$ \\
\hline \multicolumn{4}{|c|}{ Independent Variables: Institutional and Political Factors } \\
\hline common.law & Common Law & $\begin{array}{l}\text { 1: Common Law } \\
\text { 0: Civil Law }\end{array}$ & $\begin{array}{l}\text { Central Intelligence } \\
\text { Agency (CIA) database }\end{array}$ \\
\hline leg.oversight & $\begin{array}{l}\text { legislative } \\
\text { budget oversight }\end{array}$ & leg.oversight $=\sum_{i=1}^{12}\left(\right.$ leg.oversight $\left._{i}\right) / 12$ & $\begin{array}{l}\text { It was compiled by us } \\
\text { using the } 2017 \text { Open } \\
\text { Budget Survey Data. }\end{array}$ \\
\hline political.competition & $\begin{array}{l}\text { Political } \\
\text { Competition }\end{array}$ & $\begin{array}{l}\text { Number of seats held by the ruling party in the } \\
\text { legislature (\% of the total number of seats) }\end{array}$ & $\begin{array}{l}\text { Database of Political } \\
\text { Institution (WB) }\end{array}$ \\
\hline presidential & $\begin{array}{l}\text { Type of } \\
\text { Government } \\
\text { System }\end{array}$ & $\begin{array}{l}\text { 1: Presidential system } \\
\text { 0: Parliamentary system }\end{array}$ & $\begin{array}{l}\text { Database of Political } \\
\text { Institution (WB) }\end{array}$ \\
\hline audit.diversity & $\begin{array}{l}\text { The number of } \\
\text { audit types of } \\
\text { SAl }\end{array}$ & 0: Weak Audit, 3: Strong Audit & $\begin{array}{l}\text { It was compiled by us } \\
\text { using the } 2017 \text { Open } \\
\text { Budget Survey Data. }\end{array}$ \\
\hline judicial.SAl & $\begin{array}{l}\text { Countries with } \\
\text { judicial model of } \\
\text { supreme audit } \\
\text { institution }\end{array}$ & $\begin{array}{l}\text { 1: judicial model of supreme audit institution } \\
0 \text { : others }\end{array}$ & $\begin{array}{l}\text { INTOSAI Working Group } \\
\text { on Value and Benefits of } \\
\text { SAls (WGVBS) }\end{array}$ \\
\hline \multicolumn{4}{|c|}{ Independent Variables: Socio-Economic Factors } \\
\hline$g d p p c$ & Economic Level & $\begin{array}{l}\text { gross domestic product (GDP) per capita, } \\
\text { (natural logarithm) }\end{array}$ & World Bank (WB) \\
\hline democracy & $\begin{array}{l}\text { Democratization } \\
\text { Level }\end{array}$ & $\begin{array}{l}\text { Policy } 2 \text { index: }-10 \text { strong autocracy; }+10 \\
\text { strong democracy }\end{array}$ & Policy IV project database \\
\hline debt & $\begin{array}{l}\text { Government } \\
\text { Debt }\end{array}$ & Government debt (the percentage of GDP) & $\begin{array}{l}\text { International Monetary } \\
\text { Fund (IMF) }\end{array}$ \\
\hline government.balance & $\begin{array}{l}\text { Government } \\
\text { Balance }\end{array}$ & $\begin{array}{l}\text { General government net lending/borrowing } \\
\text { (the percentage of GDP) }\end{array}$ & $\begin{array}{l}\text { International Monetary } \\
\text { Fund (IMF) }\end{array}$ \\
\hline press.freedom & $\begin{array}{l}\text { Freedom of } \\
\text { Press }\end{array}$ & $\begin{array}{l}\text { 0: no freedom of press, 100: full freedom of } \\
\text { press }\end{array}$ & Freedom House \\
\hline
\end{tabular}

\section{Econometric Model}

The theoretical literature shows that there is an endogeneity problem between the external audit of Supreme Audit Institution and the fiscal transparency. In order to solve this problem, Two-Stage Least Squares (2SLS) estimation method which considers the mutual relation among variables has been used precisely. So as to be able determine the external audit of Supreme Audit Institutions, equation (1.) has been used.

external.audit ${ }_{\mathrm{i}}=\alpha+b_{1}$ debt $_{1 \mathrm{i}}+b_{2}$ democracy $_{2 \mathrm{i}}+{ }_{3}$ gdppc $_{3 \mathrm{i}}$

$$
\begin{aligned}
& +b_{4} \text { leg.oversight }{ }_{4 \mathrm{i}}+b_{5} \text { audit.diversity }_{5 \mathrm{i}} \\
& +b_{6} \text {.judicial.SAI }{ }_{6 \mathrm{i}}+b_{7} \text { government.balance }_{7 \mathrm{i}}+\varepsilon_{\mathrm{i}}
\end{aligned}
$$

In the model, index $\mathrm{i}(\mathrm{i}=1,2, \ldots, 115)$ specifies the countries, $\alpha$ specifies the constant term, $\boldsymbol{b}_{\mathrm{ii}}$ specifies the parameters to be estimated, and $\varepsilon$ specifies the error term. 
A second equation (2.) has been added in order to control the reverse causality caused by the endogeneity problem between external audit and fiscal transparency.

fiscal.transparency ${ }_{\mathrm{i}}=\alpha+\gamma_{1}$ external.audit ${ }_{1 \mathrm{i}}+\gamma_{2}$ press.freedom $_{2 \mathrm{i}}$

$+\gamma_{3}$ government.balance $_{3 \mathrm{i}}+\nu_{4}$ precidency $_{4 \mathrm{i}}$

$+\nu_{5}$ political.competition ${ }_{5 \mathrm{i}}+\nu_{6} \mathrm{gdppc}_{6 \mathrm{i}}+\nu_{7}$ common.law $_{7 \mathrm{i}}+\varepsilon_{\mathrm{i}}$

In the model, index $\mathrm{i}(\mathrm{i}=1,2, \ldots, 115)$ specifies countries, $\alpha$ specifies the constant term, $\gamma_{\mathrm{ji}}$ specifies the parameters to be estimated, $\varepsilon$ specifies the error term.

In the study, factors affecting the fiscal transparency have been determined considering the variables used by Alt \& Lassen (2006) and Ríos et al. (2016). According to this, while the institutional and political factors affecting fiscal transparency are common law (common.law), political competition (political.competition) and presidential system (presidential), socio-economic factors are economic development level ( $g d p p c$ ), democratization level (democracy), the freedom of press (press.freedom) and government balance (government. balance). Moreover, external audit (external.audit) of Supreme Audit Institution which is an internal variable has been added to the model as an explanatory variable of fiscal transparency.

\section{Empirical Results}

In Graph 1, the relation between fiscal transparency and external audit carried out by Supreme Audit Institution has been displayed. According to the scatter diagram, there is a positive correlation between the two variables. This relation supports the literature (Santiso, 2006, 2007a, 2007b).

Graph 1. The Relation between External Audit and Fiscal Transparency

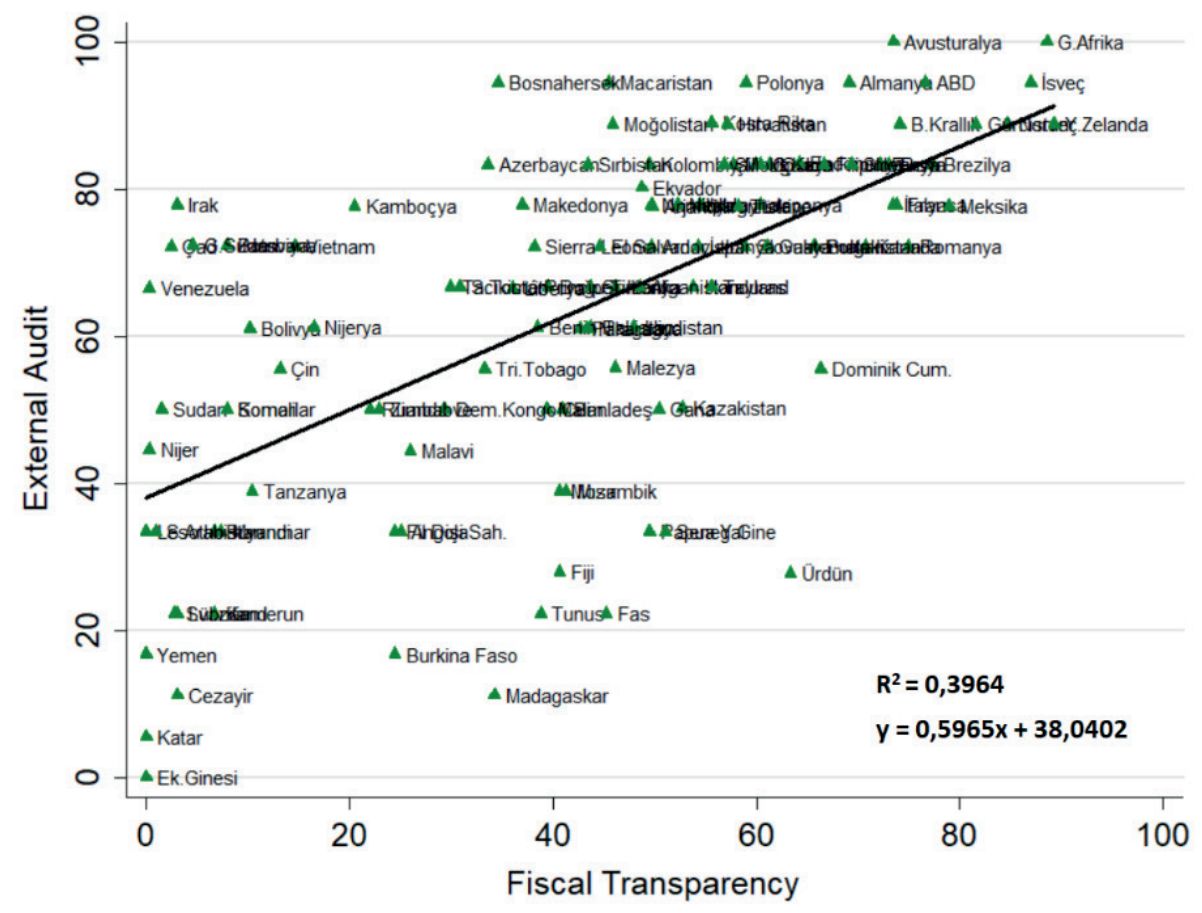


The regression results regarding institutional, political and socio-economic factors affecting the external audit of Supreme Audit Institution (Least Squares Method (OLS)) are shown on Table 2. The total number of observations in the regression is 107 . The first column contains the variable names. The second column presents the regression results of the external audit and the White $\left(x^{2}\right)$ test. The changing variance problem encountered in the regression has been eliminated by the method of robust standard errors.

Table 2. Factors Affecting External Audit

\begin{tabular}{ll}
\hline & External Audit (OLS, robust) \\
\hline Democracy & $1.01^{* * *}(0.40)$ \\
Debt & $-0.05(0.05)$ \\
\hline Government Balance & $0.78(0.57)$ \\
Gdppc & $2.58^{*}(1.47)$ \\
\hline Legislative Oversight & $0.41^{* * *}(0.95)$ \\
Audit Diversity & $3.09^{* *}(1.63)$ \\
\hline Judicial Model of SAl & $7.01^{* *}(3.68)$ \\
\hline Constant Term & $14.12(12.81)$ \\
\hline $\mathbf{R}^{2}$ & 0.57 \\
\hline Number of Observation $(\mathrm{n})$ & 107 \\
\hline White Test $\left(\mathrm{x}^{2}\right)$ & $8.81(\mathrm{p}=0.0030)$ \\
\hline
\end{tabular}

Least squares method (OLS) prediction results. Coefficients and standard errors (those are in parenthesis). Significance levels ${ }^{* *} p<0.01,{ }^{* *} p<0.05$, ${ }^{*} p<0.1$, the largest VIF value: 1.59 .

It has been concluded that democracy (democracy), gross domestic product per capita ( $g d p p c)$, legislative budget oversight (leg.oversight), audit diversity carried out by Supreme Audit Institution (audit.diversity) and the country's having judicial model of supreme audit institution (judicial. SAI) have positive and significant effects on external audit. On the other hand, it has been seen that the government debt (debt) and the government balance (budget.balance) have no significant effect on the external audit.

Over-identification (Sargan) test has been used to identify whether there is an endogeneity problem between external audit and financial transparency; and then, since there is an endogeneity problem, Two-Stage Least Squares Method (2SLS) has been used to see the effects of external audit on fiscal transparency. The result of the analysis is shown on Table 3. 
Table 3. Factors Affecting Fiscal Transparency

\begin{tabular}{lc}
\hline & Fiscal Transparency (2SLS) \\
\hline External Audit & $0.76^{* * *}(0.15)$ \\
Gdppc & $2.29(1.68)$ \\
\hline Government Balance & $0.83^{* *}(0.44)$ \\
Common Law & $0.57(4.02)$ \\
\hline Political Competition & $-0.07(0.10)$ \\
Freedom of Press & $0.27^{* *}(0.11)$ \\
\hline Presidential & $6.88^{*}(4.03)$ \\
Constant Term & $-34.10^{* *}(14.34)$ \\
\hline Number of Observation $(\mathrm{n})$ & 98 \\
$\mathbf{R}^{2}$ & 0.52 \\
\hline Over-identification (Sargan) test $\chi^{2}$ & $0.83(\mathrm{p}=0.6611)$ \\
\hline
\end{tabular}

Two-Stage Least Squares Method (2SLS) prediction results. Coefficients and standard errors (those are in parenthesis). Significance levels $* * * p<0.01$, $* * p<0.05, * p<0.1$.

As a result of the analysis, it has been observed that external audit carried out by Supreme Audit Institution is one of the determiners of fiscal transparency as well as the other factors such as government balance (government.balance), the freedom of press (press.freedom) and the presidential system (presidential). Supreme Audit Institution's conducting an effective external audit (external.audit) has a positive effect on fiscal transparency.

\section{Conclusion}

The study aims to analyze the factors affecting the external audit carried out by Supreme Audit Institution and the effects of external audit on fiscal transparency. For this purpose, the factors affecting the external audit in the sample of 115 countries have been determined by using the Two Stage Least Squares Method (2SLS); and then the effect of external audit on financial transparency was determined. Supreme Audit Institutions together with fiscal transparency are indispensable components of accountability mechanism in democratic parliamentary systems. Supreme Audit Institution carries out independent audits on the performance of executive body. An effective external audit affects fiscal transparency positively. The analysis made have demonstrated that democratization level, gross domestic product (GDP) per capita, legislative budget oversight, audit diversity of Supreme Audit Institution and judicial model of Supreme Audit Institution have positive effects on external audit. 


\section{References}

Alt, J. E., \& Lassen, D. D. (2006). “Transparency, political polarization, and political budget cycles in OECD countries". American Journal of Political Science, 50(3), 530-550.

Bringselius, L. (2015). In the absence of a Public Accounts Committee: The Swedish experience. In Z. Hoque (Ed.), Making governments accountable (ss. 148-164). London/New York: Routledge.

Feyzioğlu, B. N. (1997). Sayıştay ve Saydamlık. Sayıştay Dergisi, 8(25), 7-9.

Köse, H. Ö. (2007). Dünyada ve Türkiye'de yüksek denetim. Ankara: 145. Yıl Yayınları.

Morgner, M., \& Chêne, M. (2014). External Audit and Oversight Topic Guide. Transparency International [TI].

Posner, P. L., \& Shahan, A. (2014). Audit institutions. Içinde M. Bovens, R. E. Goodin, \& T. Schillemans (Ed.), The Oxford handbook of public accountability (ss. 488-506). Oxford: Oxford University Press.

Ríos, A.-M., Bastida, F., \& Benito, B. (2016). "Budget transparency and legislative budgetary oversight: An international approach". American Review of Public Administration, 46(5), 546-568.

Santiso, C. (2006). "Improving fiscal governance and curbing corruption: How relevant are autonomous audit agencies?" International Public Management Review, 7(2), 97-108.

Santiso, C. (2007a). Auditing for accountability? Political economy of government auditing and budget oversight in emerging economies. Johns Hopkins University.

Santiso, C. (2007b). Eyes Wide Shut? The Politics of Autonomous Audit Agencies in Emerging Economies.

Stapenhurst, R., \& Titsworth, J. (2001). Features and functions of supreme audit institutions (No. PREM Notes; No. 59). Washington, DC.

Yılmaz, H. H., \& Biçer, M. (2010). "Parlamentonun bütçe hakkını etkin kullanımının yeni bütçe sistemi çerçevesinde değerlendirilmesi”. Maliye Dergisi, 158(Ocak-Haziran), 201-225. 